\title{
Correlation between parasitemia and spleen size in patients with $P$. falciparum infection
}

\author{
Dini Lailani, MD; Munar Lubis, MD; Bidasari Lubis, MD; Syahril Pasaribu, MD
}

\begin{abstract}
Background Spleen is an important organ in immunity to malaria infection which is always affected in malaria patients. Enlargement of the spleen is one of the main clinical symptoms of malaria. Level of parasitemia is related to the risk of complications.

Objective To describe the correlation between parasitemia and spleen size in patients with P.falciparum infection.

Methods One hundred and four patients including children and adults with fever, pale, jaundice, diarrhea, and headache who visited public health centers in 5 villages in Mandailing Natal, North Sumatera were enrolled in this study. The diagnosis of malaria was based on blood smears stained by Giemsa method, while the spleen size was measured using Hackett method. Correlation between parasitemia and spleen size was tested by Spearman rank correlation.

Results Splenomegaly was found in 37 of 104 patients (35.6\%) with the size of $\mathrm{H} 1$ in $10.6 \%, \mathrm{H} 2$ in $15.4 \%$, $\mathrm{H} 3$ in $9.6 \%$. The mean parasite count between patients with and without splenomegaly was different, and the difference was significant between patients with spleen size of $\mathrm{HO}$ and $\mathrm{H} 3$. The higher the parasitemia, the bigger the spleen size was $(r=0.291 ; p=0.03)$.

Conclusion There was a correlation between parasitemia and spleen size in falciparum malarial infection [Paediatr Indones 2004;44:111-116].
\end{abstract}

Keywords: parasitemia, splenomegaly, falciparum malaria.

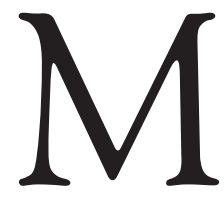
alaria is still a public health problem in many countries, including in Indonesia. The symptoms are fever, shivering, anemia, jaundice, and hepatosple-nomegaly. ${ }^{1,2}$ Diagnosis of malaria is established by the finding of malarial parasites in the blood. For the time being, the diagnosis is carried out by means of the conventional method using Giemsa staining of blood smears, either thick or thin. A thick blood smear is made for detecting and counting the parasites, whereas a thin blood smear for identifying the species. ${ }^{3}$ The degree of parasitemia is useful as a prognostic factor. Parasites in blood of more than $100,000 /$ microliter are associated with severe infection. ${ }^{4,5}$ Detectable parasitemia in immunocompromised patients causes significant symptoms, and the magnitude of parasitemia is related to the risk of death or complications. ${ }^{6}$

Spleen has an important role in defense mechanism against malarial infection. As the body's largest lymphoid organ, the spleen has a variety of immunologic functions including as a sieve for the blood removing blood cells, microorganisms, and immune complexes. ${ }^{7}$ The spleen is always affected in patients suffering from malaria; a palpable spleen is one of the main clinical symptoms. History of fever, anemia, and splenomegaly are predicting symptoms for clinical diagnosis of malarial infection in endemic areas. ${ }^{4}$ The purpose of this study was to describe the correlation between parasitemia and spleen size in patients with P. falciparum infection.

From the Department of Child Health, Medical School, University of Sumatera Utara, Adam Malik Hospital, Medan.

Presented at the $12^{\text {th }}$ National Congress of Child Health; 2002 June 30 July 4; Bali, Indonesia.

Reprint requests to: Dini Lailani, MD. Department of Child Health, Adam Malik Hospital, Medan, Indonesia. Tel./Fax. 62-21-8361721. 


\section{Methods}

A cross-sectional study was conducted in 5 villages in Mandailing Natal, North Sumatera, during the period of April $9^{\text {th }}$ to $19^{\text {th }}, 2001$. Subjects were selected through a simple random sampling method. Sample size calculation using a formula ${ }^{8}$ revealed a sample size of 96 (95\%CI, 0.5 proportion of falcipa-rum malarial patients, 0.1 bound of error). Studied participants were all children and adults who visited the public health centers with complaints of fever, pale, diarrhea, headache, and jaundice. Patients who had antimalarial drugs one week before the study were excluded. Informed consent was obtained from the patients or their parents before study. This study was approved by the institutional review board of Adam Malik Hospital, North Sumatera.

A blood examination for counting the parasites was performed by taking a drop of blood sample from the finger or toe of the subjects to make thick and thin blood smears. Both thick and thin blood smears were prepared in a same film slide. Thick blood smears were directly stained using Giemsa method for 20 minutes, while thin blood smears were initially fixed with methyl alcohol for a few seconds and then stained for 30 minutes. Subsequently, clean water was poured on the surface of stained films for 10-15 seconds and then the films were dried. The slide was examined under an ordinary light microscope. The result was considered negative when malarial parasite was not found in the blood smear, and positive if there was any. Parasite count per microliter of blood was defined as the number of malarial parasites found in every 100 white blood cells in the blood smear and multiplied by $80 .{ }^{4}$ Spleen enlargement was measured using Hackett method and classified as Hackett (H) 0-5 (Table 1). ${ }^{4}$

\section{Table 1. Spleen size by Hackett method}

\begin{tabular}{ll}
\hline H0 & Normal spleen, not palpable even in deep inspiration \\
H1 & $\begin{array}{l}\text { Spleen was palpable below the costal margin, usually on } \\
\text { deep inspiration. }\end{array}$ \\
H2 & $\begin{array}{l}\text { Spleen was palpable below the costal margin, but not } \\
\text { projected beyond a horizontal line half way between the } \\
\text { costal margin and the umbilicus measured along a line } \\
\text { dropped vertically from the left nipple. }\end{array}$ \\
H3 $\quad \begin{array}{l}\text { Spleen with lowest palpable point projected more than half } \\
\text { way to the umbilicus but not below a line drawn horizontally } \\
\text { through it. }\end{array}$ \\
H4 $\begin{array}{l}\text { Spleen with lowest palpable point below the umbilical level } \\
\text { but not projected beyond a horizontal line situated half way } \\
\text { between the umbilicus and the symphysis pubis. }\end{array}$ \\
H5 $\begin{array}{l}\text { Spleen with the lowest point palpable beyond the lower } \\
\text { limit of class } 4 .\end{array}$
\end{tabular}

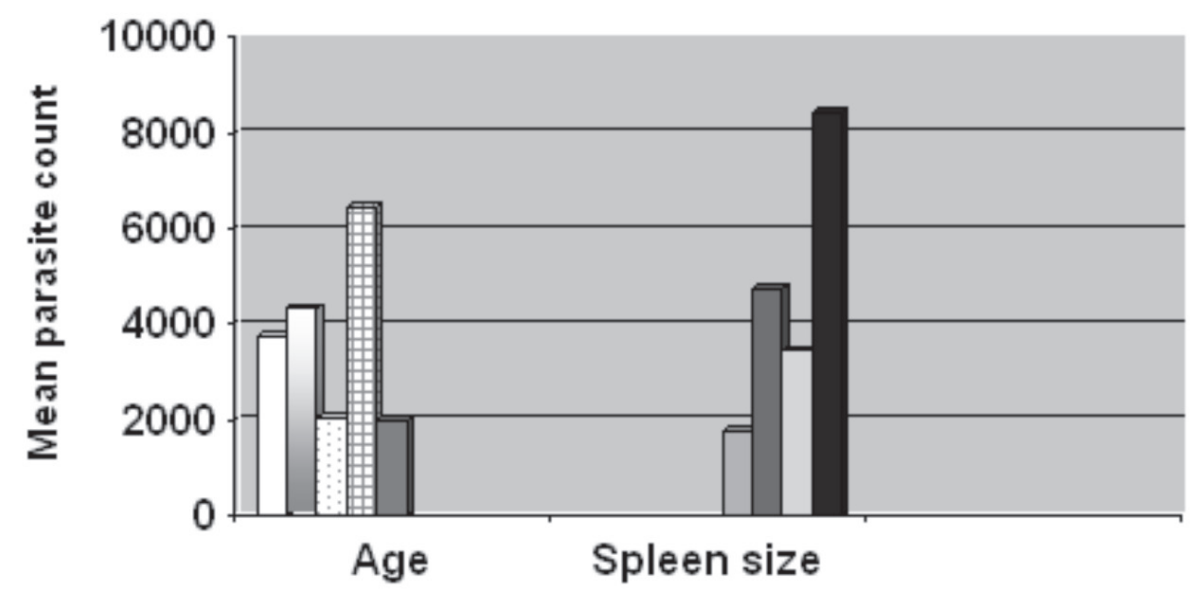

\begin{tabular}{|llll|}
\hline$\square 0-1$ y & $\square 1-5 y$ & $\square 5-10 y$ & $\boxplus 10-15 y \quad \square>15 y$ \\
$\square \mathrm{H} 0$ & $\square \mathrm{H} 1$ & $\square \mathrm{H} 2$ & $\square \mathrm{H} 3$
\end{tabular}

Figure 1. Mean parasite count according to age group and spleen size 
Statistical analysis was conducted using a computer program (SPSS version 10.5). The correlation between parasitemia and spleen size was assessed by Spearman rank correlation. Differences were considered as statistically significant if $\mathrm{p}$ was $<0.05$.

\section{Results}

One hundred and four patients, including children and adults with fever, pale, jaundice, diarrhea, and headache, were enrolled during the study period. There were $46(44.2 \%)$ males and $58(55.8 \%)$ females. The most affected age group was adults and children more than 15 years old (41.3\%), followed by children $>5-10$ years $(23.1 \%),>1-5$ years $(19.2 \%)$, $10-15$ years $(9.6 \%)$, and $<1$ year $(6.8 \%)$.

Table 2 shows the clinical findings of malarial patients. The most frequent clinical symptoms were fever $(98.1 \%)$, headache $(75 \%)$, pale $(62.3 \%)$, diarrhea $(28.8 \%)$, and jaundice $(7.7 \%)$. Thirty seven patients (35.6\%) had splenomegaly, $64.4 \%$ of HO, 10.6 $\% \mathrm{H} 1,15.4 \% \mathrm{H} 2$, and $9.6 \% \mathrm{H} 3$. No splenomegaly of $\mathrm{H} 4$ and $\mathrm{H} 5$ were found. Most splenomegaly were found in the age group of 5-10 years old (11 patients). Table 3 presents the distribution of spleen size according to the age groups.
Figure 1 shows the mean parasite count according to age group and spleen size. Although the highest mean of parasite count was in the age group of 10-15 years, statistical analysis showed no significant difference among the age groups. The mean parasite count in patients with splenomegaly was higher than those without splenomegaly. There were differences in the means of parasite count between $\mathrm{HO}, \mathrm{H} 1, \mathrm{H} 2$, and $\mathrm{H} 3$. The difference was significant between $\mathrm{HO}$ and $\mathrm{H} 3$.

Table 2. Clinical findings in malarial patients

\begin{tabular}{lrc}
\hline Clinical findings & \multicolumn{2}{c}{ Total } \\
\hline & $\mathbf{n}$ & $\%$ \\
\hline Symptoms & & \\
Fever & 62 & 98.1 \\
Pale & 8 & 66.3 \\
Jaundice & 30 & 7.7 \\
Diarrhea & 78 & 28.8 \\
Headache & & 75.0 \\
Physical examination & 101 & \\
Fever & 71 & 97.1 \\
Pale & 6 & 68.3 \\
Icterus & 37 & 5.8 \\
Splenomegaly & 67 & 35.6 \\
H0 & 11 & 64.4 \\
H1 & 16 & 10.6 \\
H2 & 10 & 15.4 \\
H3 & 0 & 9.6 \\
H4 & 0 & 0 \\
H5 & 11 & 0 \\
Hepatomegaly & & 10.6
\end{tabular}

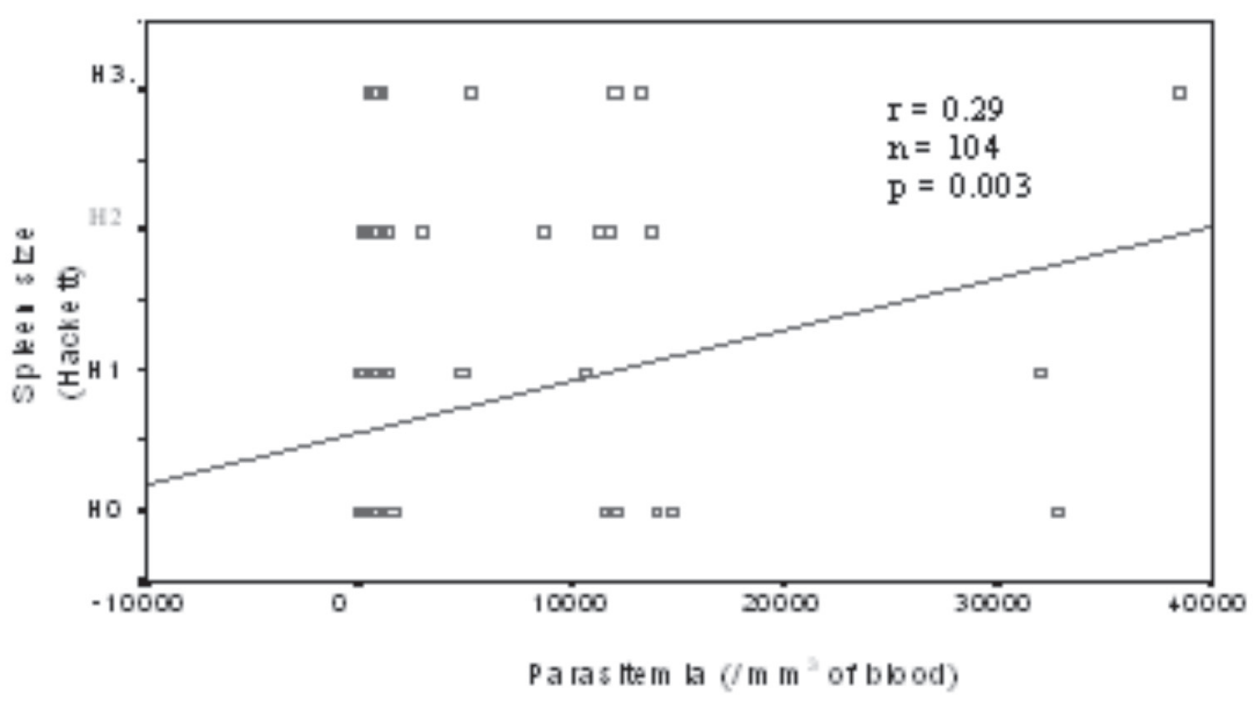

Figure 2. The correlation between parasitemia and spleen size in falciparum malarial patients. 
Paediatrica Indonesiana

Table 3. Distribution of spleen size according to age

\begin{tabular}{|c|c|c|c|c|c|c|c|c|c|c|}
\hline \multirow{3}{*}{ Age } & \multicolumn{8}{|c|}{ Spleen size } & \multirow{2}{*}{\multicolumn{2}{|c|}{ Total }} \\
\hline & \multicolumn{2}{|c|}{ Ho } & \multicolumn{2}{|c|}{ H1 } & \multicolumn{2}{|c|}{$\mathrm{H} 2$} & \multicolumn{2}{|c|}{ H3 } & & \\
\hline & $\mathbf{n}$ & $\%$ & $\mathbf{n}$ & $\%$ & $\mathbf{n}$ & $\%$ & $\mathbf{n}$ & $\%$ & $\mathrm{n}$ & $\%$ \\
\hline $0-1$ years & 4 & 3.9 & 2 & 1.9 & 1 & 1.0 & 0 & 0 & 7 & 6.8 \\
\hline$>1-5$ years & 10 & 9.6 & 2 & 1.9 & 2 & 1.9 & 6 & 5.8 & 20 & 19.2 \\
\hline$>5-10$ years & 13 & 12.5 & 3 & 2.9 & 7 & 6.7 & 1 & 1 & 24 & 23.1 \\
\hline$>10-15$ years & 6 & 5.8 & 2 & 2.9 & 3 & 1.9 & 0 & 0 & 10 & 9.6 \\
\hline$>15$ years & 34 & 32.7 & 2 & 2.9 & 4 & 3.8 & 3 & 2.9 & 43 & 41.3 \\
\hline Total & 67 & 64.4 & 11 & 10.6 & 16 & 15.4 & 10 & 9.6 & 104 & 100 \\
\hline
\end{tabular}

Figure 2 shows the correlation between parasitemia and spleen size in falciparum malarial patients. Increase in spleen size was parallel with increase in level of parasitemia with a weak correlation coefficient $(r=0.291)$. This result was statistically significant with a $\mathrm{p}$ value of 0.003 .

\section{Discussion}

This study found that the most age group that suffered from malaria was $>15$ years of age. This was in accordance with other studies conducted in Nias ${ }^{9}$ and Aceh Langsa Hospital. ${ }^{9,10}$ Our study revealed females were affected more than males, but Albar in Ternate, ${ }^{11}$ found that males were affected more than females. This distinction might be influenced more by the composition of gender for each population rather by other factors.

In the present study, malaria was uncommon among infants ( $<1$ year). This finding is supported by Lubis. ${ }^{10} \mathrm{In}$ endemic areas where transmission occurs severely throughout the year, infection among infants is uncommon since there were transplacental antibodies from mothers. The existence of fetal hemoglobin $(\mathrm{HbF})$ in infants is also the reason of protective effect against parasite's growth. ${ }^{7}$ The mechanism of this protective effect is still unclear. It is probably associated with the oxygen content, intercellular acidity and rigidity of the cellular membrane, which are different from adult hemoglobin ( $\mathrm{HbA}) .4,7$

We found that the most common symptoms in this study were fever, headache, and pale. Fever is the most common symptom in malaria, and presumably it is associated with pyrogens such as TNF, IL-1, and IL-6. ${ }^{12}$ Jacobsen reported that the level of TNF was higher in symptomatic malarial patients compared with that of asymptomatic patients, and this TNF level was correlated with the level of parasitemia and body temperature. ${ }^{13}$ In this study, we did not measure the level of this cytokine.

In endemic areas, children aged $1-5$ year-old are in a high risk period of having malarial infection due to the absence of the immunity. Infection in children older than 5 years is usually mild and will be asymptomatic in adults. Prolonged exposure to malaria results in the development of antibodies, therefore the immunity is increased by time. ${ }^{14,7}$ We found that there was no significant difference in mean parasite count $/ \mathrm{mm}^{3}$ blood among the age groups in this study (Figure 1). To our knowledge, there had been no study about the correlation between age and level of parasitemia.

In the case of parasite count above $10 \%$, exchange transfusion may be beneficial. It can reduce parasitemia more rapidly and in addition, it can restore red cell mass, platelets, clotting factors, albumin, as well as remove the harmful toxins. However the procedure may still be in trial for patients who are severely ill, did not respond adequately to antimalarial therapy especially newer drugs such as artemisin, and had parasite count of more than $10 \% .^{1}$ In this study the parasite count was not more than $2 \%$.

Hepatomegaly was found in $10.6 \%$ of subjects, while splenomegaly was found in $35.6 \%$. This finding was supported by the study of Annobil et al. ${ }^{15}$ Hepatomegaly occurs early in malaria and usually can be palpable in the first week after the onset. Hepatic sinusoids are dilated and show hypertrophy of Kupffer cells. ${ }^{12}$ Liver is an alternative organ besides the spleen as a place for eliminating the parasitized red cells. ${ }^{16}$

We found splenomegaly in $37(35.6 \%)$ patients. This result was smaller than that of other study which found splenomegaly in $45 \%$ to $75 \%$ of patients. $10,15,17$ Spleen enlargement in malaria is related to the lysis of 
Dini Lailani et al: Correlation between parasitemia and spleen size in falciparum infection

red blood cells that are infected by merozoit. There are edemas of the pulps and lymphoid and reticuloendothelial hyperplasia with the increase of hemolytic and phagocytic functions of the organ. ${ }^{12}$ In this study, splenomegaly was found predominantly in children under 10 years of age. This finding was supported by the result of Sutanto's study. ${ }^{18}$ Rita Marletta in Nias found splenomegaly predominantly in the age of $5-11$ yearold. ${ }^{9}$ Splenomegaly is common in children aged $1-10$ years where the immune response is performed. ${ }^{4}$

Considering the fact that Indonesia is a tropic country and Mandailing Natal is an endemic area, we were not able to conclude whether splenomegaly in our patients could be included as a tropical splenomegaly syndrome or not since the highest spleen size in this study was only of Hackett 3 and we did not examine the level of IgG and IgM. ${ }^{19,20}$

Total parasitemia is associated with prognosis of patients. Parasite count more than 100,000 per microliter blood indicates severe infection and bad prognosis. This study was conducted to compare parasite counts for each degree of spleen size in patients with malaria. We found that the highest spleen size was Hackett 3. The comparison of mean parasite counts for each degree of spleen size showed that mean parasite counts in subjects with or without splenomegaly ( $\mathrm{HO}$ vs. $\mathrm{H} 1, \mathrm{H} 2$, and H3) were different. Differences were also found among different degrees of splenomegaly ( $\mathrm{H} 1, \mathrm{H} 2, \mathrm{H} 3)$. The most significant difference was found between the groups of $\mathrm{HO}$ and $\mathrm{H} 3$ (Figure 1).

In conclusion, our findings showed the correlation between parasitemia and the degree of spleen size. The higher the parasite count, the bigger the spleen size is. In endemic areas, we can use these findings to predict patients with high parasitemia and prevent development into severe complications.

\section{References}

1. Harijanto PN. Gejala klinik malaria berat. In: Harijanto PN, editor. Malaria: epidemiologi, patogenesis, manifestasi klinis \& penanganan. Jakarta: EGC; 1999. p. 166-83.

2. Rampengan TH, Laurentz IR. Penyakit infeksi tropis pada anak. Jakarta: EGC; 1997. p. 185- 204.

3. Sri Purwaningsih. Diagnosis malaria. In: Harijanto PN, editor. Malaria: epidemiologi, patogenesis, manifestasi klinis \& penanganan. Jakarta: EGC; 1999. p.185-93.

4. Bruce-Chwatt LJ. Essential Malariology. 2nd ed. London: William Heinemann Medical Books Ltd; 1978. p. 72-8.

5. Langi J, Harijanto PN, Richie TL. Patogenesa malaria berat. In: Harijanto PN, editor. Malaria: epidemiologi, patogenesis, manifestasi klinis \& penanganan. Jakarta: EGC; 1999. p. 118-27.

6. Krogstad DJ. Plasmodium species (malaria). In: Mandell GL, Bennet JE, Dolin R, editors. Principles and practice of infectious diseases. New York: Churchill Livingstone; 2000. p. 2817-30.

7. Nugroho A, Harijanto PN, Datau EA. Imunologi pada malaria. In: Harijanto PN, editor. Malaria: epidemiologi, patogenesis, manifestasi klinis \& penanganan. Jakarta: EGC; 1999. p. 129-49.

8. Sastroasmoro S. Dasar-dasar metodologi penelitian klinis. Jakarta: Binarupa Aksara; 1995.

9. Rita Marleta, Harijani AM, Sustriayu N, Tjitra E. Penelitian malaria di kecamatan Teluk Dalam Nias Sumatera Utara. Cermin Dunia Kedokteran 1996;106:5-9.

10. Lubis NU. Gambaran penyakit malaria di bagian anak Rumah Sakit Umum Langsa Aceh Timur. Cermin Dunia Kedokteran 1994;94:14-5.

11. Albar H, Agustina IS, Hangewa P, Syamsiah I. Malaria pada anak di RSU Ternate. Cermin Dunia Kedokteran 1994;96:28-30.

12. Rampengan T. Malaria. In: Soedarmo S, Garna H, Hadinegoro S, editors. Buku ajar ilmu kesehatan anak infeksi \& penyakit tropis. $1^{\text {st }}$ ed. Jakarta: Balai Penerbit FKUI; 2002. p. 442-71.

13. Jacobsen PH, Mckay V, N'jie R, Olaleye B, D'Alessandro U, Zhang G, et al. Decreased antitoxic activities among children with clinical episodes of malaria. Infection and immunity 1998;66:1654-9.

14. Lubis CP. Sero epidemiologi malaria. Majalah Kedokteran Nusantara 1990;3:135-46.

15. Annobil HS, Okeahialam TC, Jamjoom AG, Bassuni WA. Malaria in children - experience from Asir region, Saudi Arabia. Ann Saudi Med 1994;14:467-70.

16. Angulo I, Fresno M. Cytokines in the pathogenesis of and protection against malaria. Clinical and diagnostic laboratory immunology 2002;9:1145-52.

17. Genton B, Al-Yaman F, Alpers MP, Mokela D. Indicators of fatal outcome in paediatric cerebral malaria: a study of 134 comatose Papua New Guinean children. Int J Epidemiol 1997;26:670-6. 


\section{Paediatrica Indonesiana}

18. Sutanto I, Pribadi W, Muljono R, Susanto L, Astuti H, Rasidi R. Penelitian seroepidemiologi malaria di daerah hipo dan mesoendemi Indonesia. In: Pribadi W, Muljono R, Sutanto I, editors. Proceedings of Malaria Symposium. Jakarta: FKUI; 1991. p. 25-36.

19. Taylor TE, Strickland GT. Infections of the blood and reticuloendothelial system. In: Strickland GT, editor. Hunter's tropical medicine and emerging infectious diseases. $8^{\text {th }}$ ed. Philadelphia: Saunders; 1999. p. 614-42.

20. Harijanto PN. Gejala klinik malaria. In: Harijanto PN, editor. Malaria: epidemiologi, patogenesis, manifestasi klinis \& penanganan. Jakarta: EGC; 1999. p. 151-64. 